\title{
IMPLEMENTASI PEMBERIAN MAKANAN PENDAMPING ASI PADA BAYI USIA 6-11 BULAN DI KELURAHAN JENGGOT KOTA PEKALONGAN
}

\author{
Swasti Artanti ${ }^{1}$, Hilda Prajayanti ${ }^{1}$, Dian Kusumawardani ${ }^{1}$ \\ Email: kusumadian.89@gmail.com \\ (Akademi Kebidanan Harapan Ibu Pekalongan, \\ Jl. Sriwijaya No 7 Kota Pekalongan Telp. 085102998866)
}

\begin{abstract}
ABSTRAK
ASI merupakan sumber nutrisi bagi bayi yang diberikan sejak awal kelahirannya hingga berusia 6 bulan. Selain mendapatkan ASI, bayi yang berusia lebih dari 6 bulan akan diperkenalkan dengan makanan keluarga yang sudah dimodifikasi. Makanan pendamping ASI (MP-ASI) inilah bermanfaat untuk memenuhi kebutuhan energi dan zat gizi untuk pertumbuhan. Namun pemberian MP-ASI di masyarakat tradisional mulai diperkenalkan kepada bayi yang berusia kurang dari 6 bulan. Penelitian ini dilakukan dengan tujuan untuk 1) 2) mengetahui pengetahuan, 3) kebiasaan ibu di Kelurahan Jenggot dalam memberikan MP-ASI kepada bayi, 4) mengetahui jenis MP-ASI yang diperkenalkan pertama kali kepada bayi, 5) jenis MP-ASI yang dikonsumsi bayi saat ini. Penelitian ini merupakan rancangan penelitian kualitatif yang dilakukan secara deskriptif. Pengambilan data dilakukan dengan wawancara mendalam kepada 2 ibu di Kelurahan Jenggot yang memiliki bayi berusia 6-11 bulan dan sudah memberikan MP-ASI kepada bayinya. Informan triangulasi penelitian ini adalah bidan, kader kesehatan, dan dukun bayi setempat. ibu dengan bayi usia 6-11 bulan ada yang memberikan ASI eksklusif kepada bayinya dan mulai mengenalkan makanan pendamping ASI setelah bayi berusia lebih dari 6 bulan. Namun, ada juga ibu yang memberikan MP ASI dini kepada bayi karena mengikuti budaya yang masih berkembang di masyarakat, yaitu sudah mulai memberikan pisang kerok kepada bayi yang berusa lebih dari 40 hari. Masyarakat di Kelurahan Jenggot masih berpegang erat pada budaya sehingga susah untuk merubah kebiasaan walaupun sudah diberikan pendidikan kesehatan oleh tenaga kesehatan, kader, maupun dukun bayi. Pendidikan kesehatan mengenai MP ASI sudah diberikan sejak masa kehamilan ibu sampai masa nifas masih belum efektif untuk meningkatkan pengetahuan ibu dan merubah budaya di masyarakat yang memberikan MP ASI dini kepada bayi yang berusia kurang dari 6 bulan, sehingga disarankan adanya pendidikan kesehatan mengenai MP-ASI kepada keluarga untuk ikut serta memberikan dukungan.
\end{abstract}

Kata kunci: MP-ASI, Bayi Usia 6-11 bulan

\section{Pendahuluan}

Air susu ibu (ASI) adalah sumber nutrisi bagi bayi, dari awal kelahirannya sampai usia 6 bulan. Nutrisi yang terkandung dalam ASI sesuai dengan kebutuhan bayi usia 0-6 bulan dalam tahap pertumbuhannya. ASI berguna untuk meningkatkan sistem imunitas tubuh bati, bahkan dapat melawan berbagai macam infeksi, seperti peradangan telinga dan infeksi saluran napas atas (ISPA) (Lowson, 2008).

Kementerian kesehatan republik Indonesia menganjurkan untuk pemberin makanan kepada bayi pada usia lebih dari 6 bulan, yaitu dengan makanan pendamping ASI. Hal ini dilakukan karena sistem pencernaan bayi mulai sempurna dan mampu mencerna makanan padat setelah berusia lebih dari 6 bulan. Bayi yang berusia kurang dari 6 bulan tidak diperbolehkan diberi makanan padat, misalnya bubur, susu formula, biskuit, pisang dan nasi lumat, dan sebagainya (Juwono, 2003). Dengan kata lain, bayi yang berusia kurang dari 6 bulan hanya mendapatkaan ASI sebagai asupan nutrisinya dalam masa pertumbuhan.

Makanan pendamping ASI (MP-ASI) adalah makanan keluarga yang sudah dimodifikasi pengolahannya agar dapat dimakan oleh bayi usia 6-11 bulan. MP-ASI diberikan kepada bayi setelah berusia lebih dari 6 bulan untuk mencukupi kebutuhan energinya dan zat gizi lainnya yang dibutuhkan untuk tumbuh dan berkembang pada usia ini.

Faktor-faktor yang mempengaruhi pemberian MP-ASI terlalu dini menurut WHO (2003) adalah:

a. Faktor internal meliputi : Pengetahuan ibu tentang MP-ASI dan pengalaman.

b. Faktor eksternal meliputi : sosial budaya, perawat atau petugas kesehatan lainnya, informasi tentang pemberian MP-ASI

Pemberian makanan pendamping ASI di masyarakat pada praktiknya diberikan sebelum bayi berusia 6 bulan. Faktor lain yang mempengaruhi pemberian MP-ASI dini yaitu karena kurangnya pengetahuan dan 
pendidikan ibu, peran keluarga dalam mendukung pemberian ASI eksklusif selama 6 bulan kehidupan pertama bayi, peran tenaga kesehatan dalam memberikan sosialisasi yang masih kurang, dan mayarakat yng masih memegang kebiasaan tradisional (kultur budaya setempat).

Budaya adalah kebiasaan turun temurun yang terdapat di lingkungan sekitar, dimana kita tumbuh dan dibersarkan sehingga akan melekat dan berengaruh pda masyarakat yang berada di lingkungan tersebut. Budaya pemberian MP-ASI kepada bayi sejak berusia kurang dari 6 bulan merupakan contoh budaya yang masih sering ditemukan di masyarakat. Tenaga kesehatan dibutuhkan untuk memberikan pendidikan kesehatan untuk merubah perilaku dan kebiasaan masyarakat dalam pemberian MP-ASI dini kepada bayi yang berusia kurang dari 6 bulan. Pemberian pendidikan kesehatan mengenai MP-ASI kepada orang tua berguna dalam pemberian stimulus yang tepat pad anak untuk tumbuh dan berkmbang dengan baik (Nursalam, 2005).

Cox (2006) menyebutkan bahwa pemberian makanan dini kepada bayi yang sistem kekebalan usus belum matang dapat menyebabkan alergi terhadap makanan. Bentuk dari alergi makanan dapat berupa peradangan pada usus (gastrointestinal), alergi pada kulit (dermatologis), maupun gangguan pernapasan sampai trjad syok anafilaktik.

MP-ASI bermanfaat untuk memenuhi kebutuhan energi dan zat giwi yang tidak dapat terpenuhi jika hanya mengkonsumsi ASI saja pada bayi yang berusia lebih dari 6 bulan. Fungsi pencernaan bayi, kebutuhan makan bayi, dan usia bayi menjadi faktorfaktor yang perlu diperhatikan dalam pemberian MP-ASI. Ketiga faktor tersebut akan berpangaruh pada bentuk makanan yang harus diberikan kepada bayi, apakah itu makanan cair, lembek, atau padat.

Jenis MP-ASI untuk bayi dapat dibedakan menjadi makanan lumat (mkanan yang dihancurkan dan disaring dan masih berbentuk agak kasar), makanan lunak (makanan yang diiolah dengan banyak air sehingga tampak berair), dan makanan padat (makanan lunak yang tidak lagi berair, seperti makanan keluarga).

\section{Metode Penelitian}

Jenis penelitian yang digunakan adalah rancangan kualitatif yang disajikan secara deskriptif melalui wawancara mendalam dengan suatu kuesioner terancang. Metode kualitatif digunakan peneliti untuk mendapatkan pemahaman tentang implementasi pengenalan MP ASI pada bayi usia 6-11 bulan.

Populasi dalam penelitian ini adalah ibu yang memiliki bayi usia 6-11 bulan di Kelurahan Jenggot. Sedangkan sampel dalam penelitian ini diambil dengan metode simple random sampling yaitu sampel yang dipilih secara acak yang akan dilakukan wawancara mendalam.

Informan triangulasi dari penelitian ini yaitu bidan desa, kader kesehatan, dan dukun bayi setempat untuk mendapatkan perbandingan jawaban atau informasi.

Wawancara mendalam dilakukan dengan beracuan pada pedoman wawancara. Adapun jumlah pertanyaan untuk informan utama ibu yang memiliki bayi usia 6-11 bulan berjumlah 5 butir pertanyaan. Sedangkan pertanyaan untuk informan triangulasi juga berjumlah 5 butir pertanyaan.

\section{Hasil dan Pembahasan}

Penelitian dilakukan di Kelurahan Jenggot, dimana penduduknya sebagian besar beragam Islam serta memegang erat budaya dan ajaran Islam dalam sikap dan perilakunya sehari-hari.

MP-ASI diberikan kepada bayi yang berusia lebih dari 6 bulan untuk memenuhi kebutuhan energi dan zat gizi yang meningkat seiring dengan pertambahan usia dan aktivitasnya. Makanan yang diperkenalkan kepada bayi usia 6-11 bulan diolah sesui dengan perkembangan sistem pencernaan bayi dalam mencerna makann, yaitu dari makanan halus, lumat, lunak, hingga makanan padat yang dikonsumsi keluarga.

a. Sosialisasi pemberian MP-ASI dari tenaga kesehatan

Tenaga kesehatan berperan serta sebagai educator yang memberikan dan menyebarkan informasi kesehatan kepada masyarakat. Bidan dan kader posyandu sudah mensosialisasikan pentingnya ASI eksklusif sudah dilakukan sejak masa kehamilan ibu. Selain itu juga disosialisasikan cara pengolahan makanan saat pertama kali memperkenalkan makanan kepada bayi yang berusia lebih dari 6 bulan.

Walaupun sudah mendapatkan informasi mengenai pemberian makanan pendamping ASI dari bidan, kader kesehatan maupun dukun bayi, masih ada 
ibu yang tetap memberikan makanan pendamping kepada bayi sebelum usia bayi menginjak 6 bulan karena saran dari keluarga yang masih mengikuti budaya atau kebiasaan lama masyarakat. Kebiasaan dan adat istiadat di masyarakat mengenai upacara 3 bulanan bayi, dimana pada upacara tersebut bayi sudah disuapi pisang kerok karena menganggap pencernaan bayi sudah bisa menerima dan mencerna makanan (Ratih dan Artini, 2013).

b. Pengetahuan ibu dalam pemberian MPASI kepada bayi

Pengetahuan dan pengalaman ibu berpengaruh pada perilakunya dalam mengenalkan makanan pendamping ASI kepada bayi. Memperkenalkan makanan pendamping ASI kepada bayi dianjurkan setelah bayi berusia lebih dari 6 bulan. Namun masih ada ibu yang memberikan MP ASI kepada bayi yang berusia kurang dari 6 bulan.

Tidak semua ibu di Kelurahan Jenggot memberikan ASI eksklusif kepada bayinya dan memberikan makanan tambahan kepada bayi yang berusia kurang dari 6 bulan. Ibu muda yang kurang pengalaman sering kali menuruti apa yang dianjurkan oleh orang tuanya, walaupun sudah mendapatkan banyak informasi mengenai pentingnya ASI eksklusif bagi bayi dan pemberian makanan setelah bayi berusia lebih dari 6 bulan dari tenaga kesehatan, kader maupun dukun bayi setempat. Hasil penelitian menunjukkan kurangnya dukungan keluarga berpengaruh pada keberhasilan ibu dalam memberikan ASI eksklusif dan pengenalan MP ASI pada bayi (Perry dan Wong, 2006).

c. Budaya masyarakat dalam memberikan MP-ASI pertama pada bayi

Budaya yang berkembang di masyarakat sekitar sedikit banyak berpengaruh pada pembentukan sikap dan perilaku orang-orangnya. Seseorang yang hidup dalam suatu kelompok masyarakat akan beradaptasi dengan budaya disekitarnya. Kebiasaan masyarakat di Kelurahan Jenggot mengenai pengenalan makanan selain ASI berupa pemberian makanan halus atau lumat kepada bayi yang berusia lebih dari 40 hari. Sampai saat ini budaya tersebut masih tetap bertahan walaupun sudah dilakukan upaya perbaikan melalui pendidikan kesehatan kepada masyarakat untuk memberikan ASI saja kepada bayi usia 0-6 bulan.

Pemberian MP ASI terlalu dini kepada bayi akan berdampak pada kesehatan, baik berupa gangguan pernapasan maupun saluran pencernaan bayi (Komalasari et al, 2015). Pemberian MP ASI dini dapat diakibatkan oleh faktor ketidaktahuan masyarakat, mitos, status pekerjaan, pendapatan keluarga, dan peran serta tenaga kesehatan yang tidak mendukung program ASI eksklusif menyebabkan penurunan ASI eksklusif dan peningkatan jumlah MP ASI dini.

d. Jenis MP-ASI yang pertama kali diberikan kepada bayi

Memperkenalkan makanan pada anak dimulai sejak anak usia 6 bulan yang diawali dengan makanan bertekstur cair atau halus, dilanjutkan dengan makanan lunak, dan pada usia 1 tahun anak sudah bisa mengkonsumsi makanan padat atau makanan keluarga. Makanan halus yang diberikan kepada bayi saat mengenal makanan dapat menghindari terjadinya permasalahan pencernaan. Informan penelitian memberikan makanan pertama pada bayi berupa bubur tepung atau nasi lunak sampai usia 8 bulan, dan selingan makan buah pada siang hari. Ukuran lambung anak masih kecil, pemberian makanan yang berbentuk cair atau bubur akan membuat anak kenyang. Pola frekuensi dalam pemberian makanan pendamping ASI pada bayi akan berpengaruh kepada status gizi pada usia 6-12 bulan (Depkes RI, 2011; Sumartini, 2011).

e. Jenis MP-ASI yang dikonsumsi bayi saat ini

Makanan yang dikonsumsi bayi saat dilakukan wawancara sudah berupa nasi tim dan sayur-sayuran rebus karena bayi sudah berusia 8-9 bulan. Makanan tambahan yang didapat dari posyandu juga terkadang diberikan kepada bayi. Jenis makanan yang diberikan di Posyandu Kelurahan Jenggot tidak dibedakan berdasarkan umur karena keterbatasan tenaga kader yang bersedia untuk menyiapkan PMT (pemberian makanan tambahan). Semua anak balita yang datang ke posyandu diberi makanan yang sama, namun PMT tersebut merupakan olahan sendiri sehingga lebih terjaga kualitas makanan yang diberikan kepada balita. 
Makanan pendamping ASI diberikan kepada bayi secara bertahap, dari makanan yang cair berangsur-angsur berubah lebih kental, agar pencernaan bayi dapat menerima dan mencerna makanan (Marimbi, 2010). Jenis makanan tambahan/PMT di Posyandu hendaknya memiliki beberapa variasi yang disesuaikan dengan umur anak dan bayi yang datang ke posyandu tersebut. Makanan tambahan dari posyandu yang sekiranya tidak bisa dikonsumsi oleh bayi akan berakhir dengan dikonsumsi anggota keluarga yang lain, sehingga manfaat dari PMT bagi pengguna posyandu akan hilang.

Pengenalan makanan pendamping ASI kepada bayi sebaiknya dilakukan setelah bayi berusia lebih dari 6 bulan. Pengenalan makanan pendamping ASI yang terlalu dini akan berakibat pada kesehatan, seperti gangguan saluran pencernaan dan saluran pernapasan bayi. Pengenalan makanan pendamping ASI dilakukan secara bertahap dalam hal bentuk makanan dan juga frekuensi pemberiannya, karena lambung bayi masih belum dapat menerima makanan dalam jumlah banyak dan berbentuk padat sekaligus.

\section{Kesimpulan}

Hasil wawancara kepada ibu yang memiliki bayi berusia 6-11 bulan menunjukkan bahwa tenaga kesehatan dan kader kesehatan di Kelurahan Jenggot sudah mensosialisasikan MP-ASI kepada ibu-ibu sejak masa kehamilan hingga pasca persalinan. Namun hal ini masih belum sepenuhnya mampu merubah kebiasaan masyarakat dalam memberikan MP-ASI kepada bayi secara benar. Tidak semua ibu memberikan ASI eksklusif kepada bayi dan memberikan MP-ASI dini karena keterbatasan pengetahuan, dan budaya masyarakat sekitar yang masih memberikan makanan tambahan kepada bayi yang berusia lebih dari 40 hari. Hal ini dilakukan ibu agar bayi lebih kenyang dan tidur nyenyak, sehingga tidak merepotkan ibu saat melakukan pekerjaan rumah tangga lainnya. Jenis MP-ASI yang pertama kali diberikan oleh ibu adalah makanan yang bertekstur cair dan halus.

Disarankan untuk mengikutsertakan keluarga dalam pemberian pendidikan kesehatan mengenai pentingnya ASI eksklusif dan makanan pendamping ASI, sehingga dapat memberikan dukungan kepada ibu-ibu yang memiliki bayi.

\section{Daftar Pustaka}

[1] Cox, S,. 2006. Breast Feeding with Confidence. Panduan Untuk Belajar Menyusui dengan Percaya Diri. Jakarta: PT Elex Multimedia Computindo

[2] Depkes RI. 2011. Pelatihan Konseling Makanan Pendamping Air Susu Ibu (MPASI). Kementrian Kesehatan RI, Direktorat Bin Gizi. Jakarta

[3] Effendy N. 1998. Dasar-dasar Kesehatan Masyarakat. Jakarta: Penerbit Buku Kedokteran EGC

[4] Juwono L. 2003. Pemberian Makanan Tambahan. Jakarta: Buku Kedokteran EGC

[5] Lowson, Margaret, 2008. Makanan Sehat Bayi dan Balita. Jakarta: Dian Rakyat

[6] Kumalasari SY; Sabrian F; Hasanah O. 2015. Faktor-Faktor yang Berhubungan dengan Pemberian Makanan Pendamping ASI Dini. JOM; 2 (1): 1-11

[7] Marimbi. 2010. Tumbuh Kembang, Status Gizi dan Imunisasi Dasar pada Balita. Yogyakarta : Nuha Medika

[8] Nursalam, dkk. 2005. Asuhan Keperawatan Bayi dan Anak (Untuk Perawat dan Bidan) Edisi 1. Jakarta: Salemba Medika

[9] Perry SE, Wong DL. 2006. Maternal Child Nursing Care, Third Edition. USA: MOSBY

[10] Ratih DMIK, Artini B. 2013. Gambaran Faktor-Faktor yang Mempengaruhi Pemberian MP ASI Dini di RW 1 Kelurahan Ngagel Kecamatan WonokromoSurabaya. Surabaya: Stikes William Booth Surabaya.

[11] Sumartini, S. 2011. Pengaruh Pola Pemberian Makanan Pendamping ASI (MP-ASI) Terhadap Status Gizi pada Bayi 6-12 Bulan di Kecamatan Medan Amplas. diakses dari http://repository.usu.ac.id/handle/1234567 $89 / 33100$

[12] WHO. 2003. The World Health Report 2003 - Shaping The Future. 